\title{
When Gods Cry: Exploring Environmental Crisis Through Literature Inspired by the Indigenous People’s Experience
}

\author{
Genevieve Jorolan-Quintero \\ University of the Philippines Mindanao, Davao City, Philippines
}

\begin{abstract}
The recent devastation caused by natural calamities in the Philippines has prompted the government to initiate programs that might not altogether prevent but at least minimize the dire effects of future disasters. Among these programs are the information campaigns to promote awareness among the communities in calamity-prone areas. Several symposia that provide venue for the discussion of environmental "bads" have been conducted, but none yet has explored the perceptions of the indigenous peoples, staunch "defenders" and protectors of the environment who themselves are victims of such calamities. This paper seeks to highlight the perceptions of the indigenous people on the causes and impact of environmental "bads" through literature inspired by their experiences. When Gods Cry is an unpublished anthology of fiction inspired by the author's interaction with indigenous communities in southern Philippines while doing research on oral traditions. Three works of fiction are discussed in this paper, namely: The Old Man and the Mountain (2012), Loom of Dreams (2012), and Waterfall (2012). Each of these works highlights the indigenous people's struggle to protect their ancestral domains and the environment, their home, against external factors. Thematic literary analysis is used in the discussion of the contents of each work.
\end{abstract}

Keywords: Philippine indigenous communities, oral traditions, folk lore

\section{Introduction}

Literature is a powerful tool that can be wielded to affect some form of change. When a writer writes, he or she is guided by a clear objective, a purpose which he or she hopes will translate to the readers in the way it is intended to. All this talk about global "bads" puts the writer in a position to wield this power to scrutinize the issue, trace its causes, highlight its effects, and induce the reader to do something about it. This is what the written word can do.

The author has done research, and she is still doing research, that seek to salvage, and disseminate knowledge about indigenous oral traditions, folk literature in particular. Her aim is to get them recorded, written down, and published before they are lost to oblivion, and thus deprive the present and future generations the privilege to learn and understand the legacy and wisdom of the past.

The author's trips to the mountains and remote towns of Mindanao in the southern island of the Philippines in order to be with the indigenous communities yielded not only a significant collection of folk

Genevieve Jorolan-Quintero, Ph.D. in Education Administration, Humanities Department, College of Humanities and Social Sciences, University of the Philippines Mindanao. 
literature, but also provided her with the opportunity to learn about their belief systems, through their stories, their songs, and their proverbs. Her was humbled by the richness of their folklore, and awed by their eloquence in articulating their concept of the relationship between the humans, nature, and the gods and spirits. From this, the author started writing stories inspired by the experiences of the tribes and put these stories together into an anthology entitled When Gods Cry (2013). The 10 works the author has written for the anthology embody the perception of the indigenous people on the causes and consequences of environmental destruction.

\section{When Gods Cry: Retelling the Stories of the Folk}

The author will briefly discuss here three of the stories included in the anthology: Waterfall, Apo (The Old Man and the Mountain, 2012), and Loom of Dreams (2012).

Here is a common legend meant to explain the origin of a waterfall:

Liwan was a princess forced by her father to marry a man she didn't have feelings for. She loved another man, a commoner named, Dyomabok. On the night before her wedding, Liwan secretly met with Dyomabok, and pleaded with him to take her away from the palace. The two managed to leave the palace, but the king learned about their escape. He then led the palace guards in pursuit of the lovers. There was no escape for them when they came at the edge of a ravine. Then they raised their eyes to the heavens and prayed to the Great Spirit to save them. They held hands and jumped off the cliff. The whole place was suddenly covered with fog, and there was thunder and lightning. They dissolved into thin air, and in their place emerged the rushing waters of a waterfall. (Jorolan-Quintero, 2012, p. 290)

This legend varies from one place to another. Despite the variations in the narrative, the basic elements are present: a story about forbidden love, and the intervention of a god or the great spirit. The author used these basic elements as the foundation of her story "Waterfall". For the legend, she added a twist: turning Dyomabok into an eagle instead of both characters turning into a waterfall; the eagle and the waterfall being strong motifs in Philippine folklore.

Liwan's hand slipped from Dyomabok's grip as his arms changed into wings. Dyomabok watched horrified as his beloved fell, but was surprised as she dissolved and turned into water. Liwan had transformed into a waterfall, and Dyomabok into an eagle. (Jorolan-Quintero, 2012, p. 291)

The author further added details that were intended to highlight the implications of environmental destruction.

Legend had it, that the spirit of the waterfall protected all those who came to drink. When a creature was harmed, when blood was spilled, it was believed that the spirit would turn its rage against all of humanity. The gentle cascades would then turn into a rushing torrent, which would devour anything in its path. According to the elders of the tribe, this had happened before. The waters of the waterfall had covered the entire forest, drowning all creatures. No one and nothing were spared. (Jorolan-Quintero, 2012, p. 283)

Folklore links us with the past and provides us with a glimpse of how our ancestors lived and what they believed in. This concept reflects what a popular Philippine proverb asserts: "Ang siyang di lumingon sa pinanggalingan ay di makararating sa paroroonan" (whoever does not look back to his/her past will never arrive at a destination). Because of the accelerated influx of modern technology and the influence of modern living, it is evident that interest in folklore and the study of it have diminished (http://folklore.philsites.net/). However, the meanings and values we adhere to in the present are still influenced by those of the past. Sometimes, we do 
indirectly seek the advice of the elders, we seek the wisdom of the past in order to cope with or shed light to the "badness" we experience in the present.

When the author wrote, Loom of Dreams (2012), Apo (2012), and Waterfall (2012), her objective was to lend a voice to the people of the mountain tribes who are bound to silence and to helplessness by those in the lowlands who claim power and authority over their ancestral lands, and those who do not understand the value and significance of their traditions. She is inspired by the wisdom of the tribal folks whose concern for their environment, their home, is intertwined with their spirituality, their belief in the omniscient powers of the "Magbabaya”, the Supreme Spirit, and the spirit guardians of the creatures in Nature.

\section{Environmental Crisis, the Indigenous Peoples Experience, and Literature}

Progress and modernization have been the constant excuses for the abuse, the exploitation, and eventual destruction of nature-a sad reality in many parts of the Philippines. The recent typhoons that destroyed many lives and properties in the southern part of the country are attributed to global warming, and global warming is blamed on the destructive activities of the human society. Yet, to the indigenous people, global warming is an unfamiliar concept. While majority would point a finger to it as the culprit, the tribes seek the wisdom of the ages, turn to spirituality and their myths and legends in seeking for explanations. To them, myths and legends are lessons. They ring with truths. For modern society, we refer to history in our quest to understand past events and history being a truthful proven narrative. Modern society views myths and legends as pseudo-scientific explanations of natural phenomena. But the indigenous people revere their myths and legends which are narratives of life, and this requires faith.

The indigenous people believe that their relationship with their gods is essential to their lives. There is this reward-punishment bond between gods and humans, mostly, dependent on the moods and the pleasure of the gods. They could help humans, but also destroy them. Their benevolence could result to prosperity and comfort. Their anger could cause natural calamities such as floods and earthquakes and eventually death. To avoid these, humans must, therefore, be cautious in dealing with the gods. Pleasing the gods brings peace, prosperity, and contentment. But disrespecting them and causing them to be angry mean punishment, chaos, and death.

A week after the devastating typhoon hit the southern part of the Philippines on December 2012, the indigenous communities who were also victims of the calamity performed a ritual in the worst hit area. A "babaylan", a priestess, prayed to the gods acknowledging their role in the chaos, and at the same time, appeasing their anger, praying for the lost lives, appealing to the gods not to punish them in the same way again, and promising to take care of nature which people have destroyed causing the anger of the gods. For the indigenous people, it is the abuse and disrespect for nature that is the root cause of this punishment. Had the people been more conscientious about the fragility of nature and cautious of the anger of the gods, then none of these could have happened.

It is this collective view that guided the author's stories. At this point, may she share with you excerpts from three of the 10 stories in the anthology When Gods Cry.

\section{Excerpt From Apo (The Old Man and the Mountain)}

The story about Apo highlights the indigenous people's belief system closely linked to nature and their environment. The spirits of nature are benevolent to humans; but as it is gradually destroyed by the humans 
themselves in the name of progress and development, nature retaliates by causing catastrophic calamities. Apo is the name of the mountain in the story, but the term is also a title given to the male elders of a tribe. In a family set up, the term also literally means Grandfather.

Just as the sun was half way behind the mountain, Apo Akdu raised his head, looking straight at the mountain peak. He raised one hand and called on the spirit of the mountain; his face glowed from the rays of the setting sun. He called on the spirit of the forest. A soft breeze stirred the leaves of the mango tree. From afar, the rushing water of the waterfall carried with it the voices of the spirits. Salumnay looked at her father. The creases on his forehead had deepened. She had always been awed at how her father and the mountain seemed to communicate with each other.

“Ama..?”

"Yes...Yes...” Apo Akdu was nodding, a sad expression on his face.

"The waterfall will soon be gone, Salumnay. The forest too. Soon there will be no more baboy ramo. The spirits are sad...bad things are still to come...” Apo Akdu clutched his daughter's hand. "The mountain is in pain”.

Salumnay met Ikong's eyes. They both looked towards the mountain. The glow from the sun was gone, covering the peak in semi-darkness. Suddenly, they felt the ground move. They drew closer.

"The mountain is in pain, Salumnay. The mountain is in pain..." (Jorolan-Quintero, p. 15)

\section{Excerpt From Waterfall}

This story is inspired by the recent devastating floods that destroyed many lives and homes in the southern part of the Philippines. Just like Apo, Waterfall deals with the destructive tendencies of certain groups of people in society who have no qualms in destroying nature for material progress. Here, the indigenous community was manipulated and deceived to give up their rights over their ancestral land to a greedy politician who collaborated with a business company intent on harnessing the powers of the waterfall to provide electricity to the lowlands. The legend earlier cited, that of Lumnay and Dyomabok, is integrated in this story. It is the anger of the gods and the spirits of nature over the abuses of the environment by humans that causes the deluge.

The panic-stricken parents rushed to the clearing, gripped with foreboding, as the sound of gunfire continued. Vita and Luna were in the clearing too. They held one another, silently praying and hoping that Kilat and Gambong and their friends were safe...

Just at that moment, the eagle swooped down the waterfall, squawking. This time, it didn't fly down playfully as it used to; nor did it touch the cascading waters with its wings. But it deliberately plunged straight to the bigger pool, its claws aimed at one of the men standing at the banks. The man was stunned, not expecting the attack, and was unable to protect himself from the eagle's claws. He screamed when the sharp claws scratched his cheek. The eagle once again flew upwards, then dived back, this time eyeing the man in the smaller pool. But the man was ready for it. He aimed his gun at the large bird and fired. The eagle spiraled down, its wings touching the cascades, as if in a final farewell. A red spot stained its breast and, as the blood dripped from the body of the fallen bird, a loud roar was heard. From up the banks of the source of the waterfall, the guards noticed the sudden swelling of the river.

Those in the village felt the ground shake. And then, they heard the roaring sound before they saw the wall of murky water rushing towards them. Their muffled screams were immediately drowned by the thundering waters. The flood swept away everything and everyone in its way. The following day, news of the devastation caused by the deluge filled the airwaves. They talked about a sudden flood in the absence of a typhoon; not even a hint of rain because the skies were summer clear on that fateful day. They talked about rushing, murky waters from the mountains, destroying towns and cities in the lowlands. They sought for explanations. There was none; for who could explain the wrath of the spirits. (Jorolan-Quintero, p. 371)

\section{Excerpt From Loom of Dreams}

The woven craft of the indigenous communities in the Philippines are significant not only because of the craftsmanship, the beauty, and the uniqueness of its designs, but also because of the stories and belief systems 
they portray. One of these is the dagmay, the woven fabric made of abaca fiber created by the southern tribes in Mindanao. The story provides a detailed description of the dagmay design, and how it shows the connection between the gods, the humans, and nature. Similar to the Apo and Waterfall, Loom of Dreams also focuses on the importance of environmental protection and respect for the spirits of nature who are its protectors.

As the moon moved between clouds, its rays created a spotlight directed on the branches of the tree. And there, illumined by the moon, was the dagmay, draped as if by an invisible hand over a branch, its length teasing the tips of the grass at the foot of the tree. The dark abaca fabric slightly swayed. The moonlight paused on the dagmay, mesmerized by it, waiting to witness the transformation. Slowly, threads of gold and red and white appeared, weaving themselves in and out, until shapes gradually emerged. Just then, a cloud covered the moon. Tedi sat up, gasping for breath. She looked around the room. It was dark. Beside her on the mat lay her grandmother. Ompo Anding's breathing was steady. Tedi closed her eyes tight, willing herself to recapture the images of her dream. She could still make out the movements of the gold and red and white threads. (Jorolan-Quintero, p. 45)

Ompo Anding was now touching a golden figure, shaped like a man. Below it was a diamond-like form, its tip touching the next figure, a smaller version of the one above; then there was the intricate shape that looked like two small diamonds attached to each other, and below it appeared what appeared to Tedi as an alligator. "See here, Budi", Ompo Anding explained. "The topmost figure is the Magbabaya. And this here symbolizes the connection between the spirit world and ours. This figure here stands for the human race. And this is Nature that binds us with the other creatures. And this is Nature that binds us with the other creatures. The whole dagmay is the world, Budi, our world. As long as the Tagamaling chooses the worthy one to keep this tradition alive, our people, our tribe shall continue to live...As long as the Tagamaling continues to reveal herself to us, our people will be safe, there will always be order in the universe...” Nobody in the village had ever copied the design of Ompo Anding's dagmay. Many weavers had tried, but the design refused to take shape on their looms. Legend has it that nobody can weave the intricate design unless it appears in her dream. (Jorolan-Quintero, p. 53)

Among the indigenous communities in the southern island of the Philippines, this woven tapestry made of abaca fiber is known as dagmay among the Mandaya, and tinalak among the Bagobo and Tiboli's. The dominant colors are red, black, brown, white, and an occasional yellow. On the tapestry can be discerned symbolic figures which are representations of people and nature. A crocodile and a body of water represent nature, arranged alternately with the human figure. The whole tapestry tells a story. The autor has heard three different versions of it. The theme is constant though: the interdependence of people and nature, and the benevolence of the Supreme Being.

\section{Conclusions}

The author's stories are welded together by one element: the indigenous people's view on the bond between the gods, nature, and humanity. Their folklore embodies the wisdom of the ages solidified by experience and faith. Because of the influx of modernization and the obsession for new technologies, folklore is on the verge of being forgotten and rendered as insignificant. There is hope though —and this is when writers write the stories down for posterity.

In his brief preface to the Anthology, Sharlow Mohammed, a novelist from the Caribbean, has this to say:

Genevieve's Anthology provides for entertaining and informative reading. We could wish for more...there are many urgent and important lessons for us. Foremost perhaps, is how the tribes manage to preserve and maintain the natural environment, as against those hostile to Nature. (Jorolan-Quintero, 2012, p. 2)

When Gods Cry is an attempt to concretize the experiences of the indigenous folks and their perceptions 
on how environmental protection is tantamount to achieving lasting peace and sustainable development which they themselves find difficult to articulate. When Gods Cry hopes to lend a voice to the indigenous folks as they cry out silently to put a stop to the abuses and misuses of nature. It is time to heed this cry.

\section{References}

Eugenio, D. L. (2001). Philippine folk literature: The epics. Quezon City: University of the Philippines Press.

Eugenio, D. L. (2007). Philippine folk literature: An anthology. Quezon City: University of the Philippines Press.

Gaspar, K. M. (2000). The Lumad's struggle in the face of globalization. Davao City: Alternate Forum for Research in Mindanao. Jorolan-Quintero, G. (2012). When gods cry (Unpublished manuscript).

Sharlow, M. (2003). Writing the novel. Nebraska: Sirens Publications.

Sharlow, M. (2004). When gods were slaves. Nebraska: Sirens Publications.

Talinghaga. (2002). Introduction to Philippine Folklore. Retrieved from http://folklore.philsites.net

Valderama, U. C. (1987). The colourful mandaya: Ethnic tribe of davao oriental. Davao City: Tesoro's Printing Press. 